\title{
Active and passive fire protection system in academic building KH. Mas Mansur, Islamic University of Indonesia
}

\author{
M. Ragil Suryoputro*, Fajar Aga Buana, Amarria Dila Sari, and Fety Ilma Rahmillah \\ Department of Industrial Engineering, Islamic University of Indonesia, Jl. Kaliurang Km 14.5, Yogyakarta, Indonesia
}

\begin{abstract}
According to the theory of fire triangle, the existence of combustible materials, heat, and oxygen can cause fire disaster. KH. Mas Mansur building, Islamic University of Indonesia has a fire protection, but rarely to be checked regularly and the number of equipment is less standard as well as the lack of an evacuation route map to facilitate the evacuation process. Inside the building also does not provide safety signs such as the evacuation directions, exit, and warning in case of fire. Therefore, researchers analysed the infrastructure of prevention and control in the building KH. Mas Mansur. Researchers used the method of observation, interviews, and checklist to know the condition directly, and compare with the standard regulations. Results concordance rate of existing infrastructure is $67 \%$ fire extinguisher, hydrant box $56 \%, 71 \%$ alarms, sprinkler $0 \%, 40 \%$ detectors, emergency doors $71 \%, 50 \%$ emergency stairs, assembly point $0 \%$ and directions $0 \%$. The current results were below the standard of at least $80 \%$. As for recommendations, researchers create a new evacuation map then put the existing infrastructure according to standard regulations, and it had consulted with the specialist of Occupational Safety and Health in the field of fire.
\end{abstract}

\section{Introduction}

Fire is a flame both small and large in an undesired place, situation and time which detrimental and generally difficult to control. Fires in some areas increase annually, including in Sleman, Yogyakarta as presented in Fig 1. Figure 1 is derived from the Technical Implementation Unit (UPT) of the fire department in Sleman, Yogyakarta. It shows that almost every year incidence of fires in Sleman, Yogyakarta increases. There were 661 events of fire incidents during 2007 until 2015 with an average of 73 events per year, so there were six times fires in a month, and the highest incidence frequency was in 2015.

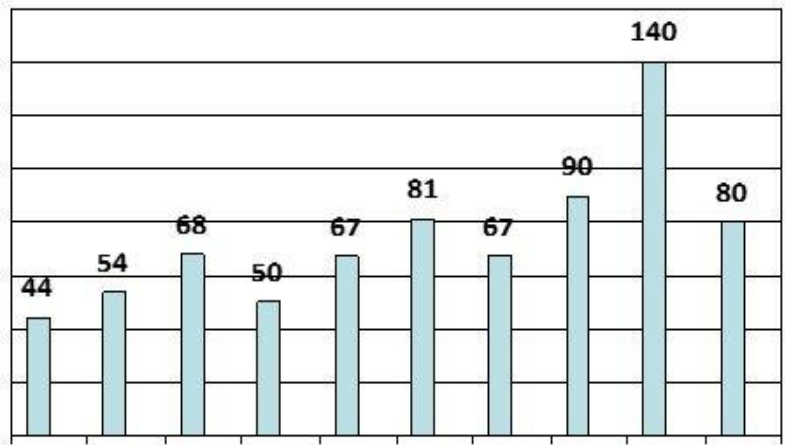

2007200820092010201120122013201420152016

Fig 1. The incidence of fires in Sleman, Yogyakarta (Source: UPT Firefighters, Sleman, Yogyakarta)

Some scholars do research about safety management system of fire protection in universities $[1,2]$ and student accommodation [3] by using various methods such as observing the documents, interview, and simulation. While [4] and [5] study the factors caused the fire by using fault tree analysis; [6] compare the safety level private and state school in Iran; [7] develops fire risk assessment method for heritage building in Malaysia. The frequent fire accidents in some universities [2] show a lack of student understanding of fire safety, campus-resistant construction and distrust in security situations in the event of a fire. Some fire accidents also happened in some universities in Indonesia [8-10]. Therefore, it is necessary to do a prevention. However, none research has done toward fire protection system in KH. Mas Mansur building, Islamic University of Indonesia which was established in 2010. Some of the existing rooms in KH. Mas Mansur building has fire extinguishers (APAR) but rarely checked regularly, and the number of equipment was insufficient as well as less standard and lack of an evacuation route map to facilitate the evacuation process. In the building also does not have safety signs such as evacuation signs, exit, and warning in case of fire. Hence, the importance of the prevention of firefighting infrastructure needs to be improved so that every person who was in the building KH. Mas Mansur, the Islamic University of Indonesia feel safe.

This study emphasizes the method of observation, interviews, and a checklist to make a comparison between the current level of fire protection system of KH. Mas Mansur building and the regulatory standards as well as to make the evacuation map for fire prevention and suppression.

\footnotetext{
* Corresponding author: ragil.suryoputro@uii.ac.id
} 


\section{Theory}

Traditionally the concept of Fire Triangle, which visually represents Fuel, Heat, and oxygen, is used to symbolize the necessary conditions for the creation of fire. Fire cannot be created if there is a missing part of the triangle. Once the fire has created, the fourth component then appears, that a complex sequence of Chemical Chain Reaction. Fire will not be created if one component of fire triangle (oxygen/fuel/heat) is lost. In addition, fire will not continue if one of the tetrahedron components (oxygen/fuel/heat/chemical chain reaction) is lost. According to [11], fire can be classified as follows: class $\mathrm{A}$ is while the fire of solid materials except for metal, and dry chemical can be used to extinguish the fire; class B is liquid or a gas fire; class $\mathrm{C}$ is the fire of electronic materials; while class $\mathrm{D}$ is the fire of metallic materials. Dry chemical, halon gas, and Carbon Dioxide $\left(\mathrm{CO}_{2}\right)$ can be used to extinguish the fire of class B, C, and D.

According to [12], the active fire protection system is a fire protection system that completely comprises either manual or automatic fire detection systems including fire extinguisher (APAR), hydrant box, fire alarm, sprinkler and fire detectors. While the passive fire protection including the emergency door, emergency stairs, exits and assembly point to prevent accidents or injuries during evacuation in the event of an emergency.

\section{Methodology}

The method in this study is using interviews, observation, and checklist. Review methods are as follow:

\subsection{Interviews}

Interviews were conducted from several sources; respondent 1 is a security guard in the building $\mathrm{KH}$. Mas Mansur, respondent 2 is an employee in charge of infrastructure building, and respondent 3 is a fire expert from the Department of Labor and Social Affairs, Sleman, DIY.

\subsection{Observation}

The collection data based on observation carried out in building KH. Mas Mansur and its surrounding. It includes infrastructure conditions of active and passive fire protection including fire extinguisher (APAR), hydrant box, fire alarm, sprinkler, fire detectors, the emergency door, emergency stairs, exits and assembly point [12].

\subsection{Checklist}

A checklist is used in comparing the actual condition of the existing infrastructure and the standard fire regulations such as from [12]-[19]. The weight rating refers to [15] which is shown in Table 1 . Then the result of this comparative analysis was used to create evacuation route mapping.
Table 1. Level of fire audit assessment

\begin{tabular}{|l|l|c|}
\hline \multicolumn{1}{|c|}{ Score } & \multicolumn{1}{|c|}{ Conformance } & Reliability \\
\hline$>80-100$ & As required & Good \\
\hline $60-80$ & $\begin{array}{l}\text { Installed but small amount of } \\
\text { installation unfulfilled the } \\
\text { requirement }\end{array}$ & Enough \\
\hline$<60$ & Not proper at all & Less \\
\hline
\end{tabular}

Source: Research and Development Center of Settlement (2005)

\section{Results and Discussion}

\subsection{Interview}

Three people were interviewed in this study. Respondent 1 said that the infrastructure is good enough such as a fire extinguisher and hydrant box, but the only problem is regarding maintenance. The check is only done if the fire training will be held. There is also no data collection regarding the number of APAR. A fire training conducted by the university was held for security personnel while indoor and outdoor fire workshop sponsored by industrial engineering department which held a few months ago. The training provides more insight about the importance of fire prevention and how to countermeasure.

The second interview was conducted with respondent 2 as the person in charge in term of an infrastructure of the building KH. Mas Mansur. The building was built in 2004 and completed by fire prevention and control tools such as fire extinguisher, hydrant box, alarms and heat detectors. However, the number of existing infrastructure is not known because of the lack of data and technical information constraints. Hydrants ever used to clean volcanic ash when an eruption of volcanic mountain happened, and APAR was periodically replaced according to the validity period. However, the thermal detector was never being tested. The faculty tends to prioritize fire extinguisher on every laboratory than that in the office space and lecture room, due to the danger level. The laboratory has higher danger because of many chemical solutions, electronic tools, etc.

The third Interview was done with $\mathrm{Mr} \mathrm{S}$ as the fire expert from Department of Labor and Social Affairs, Sleman, DIY. Before interviewing respondent 3, prior observation towards building KH. Mas Mansur had been done. Actually, the building already equipped with fire protection such as fire extinguisher, hydrants, alarms and heat detectors. However, when the observation conducted, the alarm condition was not working so it cannot be tested whether the detector work or not. Second, the hydrant boxes were incomplete such as no nozzle and a fire hose. It can be stated that the maintenance of fire hydrant and alarm has not run optimally. Then, there was no APAR at some points, even if it is available, it was not placed properly. So, it is necessary to optimize the function of available alarm and hydrant, place APAR properly, and give mark as well as socialize how to use it. Regarding the evacuation route, since many activities held in the building, when there is a fire can cause panic, potentially. Therefore, the evacuation path must exist. 


\subsection{Observation}

Some active and passive fire protection in the building KH. Mas Mansur were found. The condition of the infrastructure suits with the result of interview toward three people. Figure 2 shows some of the fire protection tools.
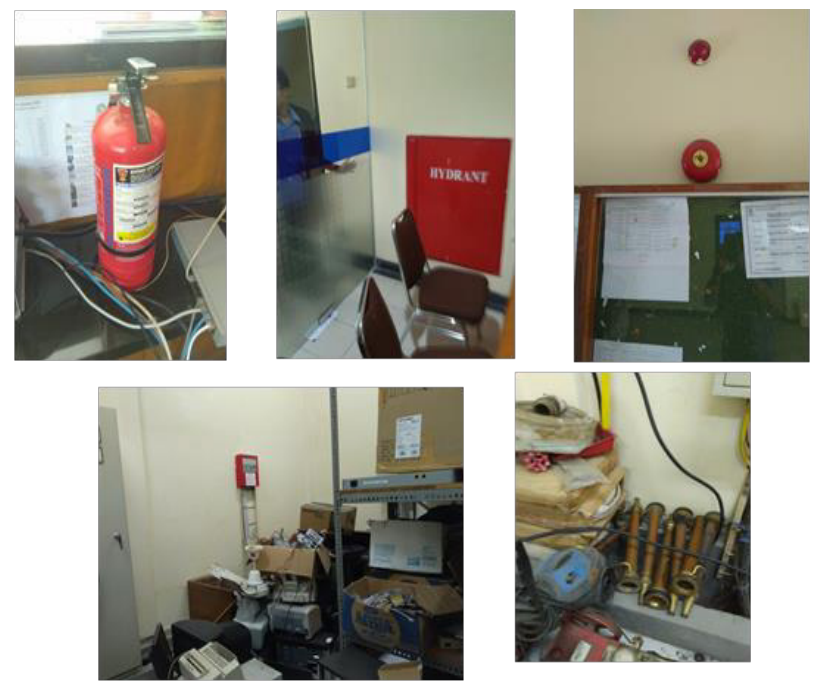

Fig 2. Active fire protection
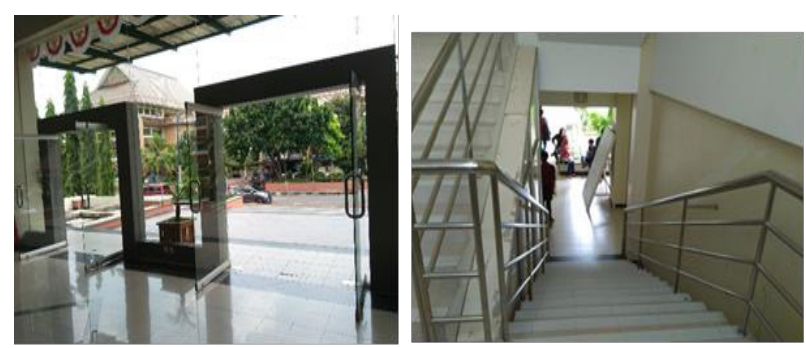

Fig 3. Passive fire protection

\subsection{Checklist}

The suitability of the existing condition towards the standard of active fire protection as follows. 10 out of 15 requirements related to APAR [12] were fulfilled, so that the score is $67 \%$ means conformance level is enough. While 5 out of 9 requirements of hydrant according to [13]. It means the suitability with Indonesian National Standard is less. Regarding the alarm, there are two specifications needed which are the availability of the alarm and the signal of the alarm that is tested. Since only one fulfilled, the score is $50 \%$ or not in accordance with SNI. Whereas the existing condition of sprinkler at building KH. Mas Mansur does not fulfil 13 requirements of [17] which means not good. Regarding the heat detector, 2 out of 5 requirements are fulfilled which are the availability of detector in all rooms and the ease of reaching the detector. It means $40 \%$ and categorized as not good level. Therefore, the average suitability of active fire protection facilities in the building KH. Mas Mansur is $42.6 \%$ which means less good. The low fulfilled requirements because there are still many active protection facilities that do not meet the standard terms and conditions. It can be seen from each active protection that is less than $80 \%$ (Fig. 4).

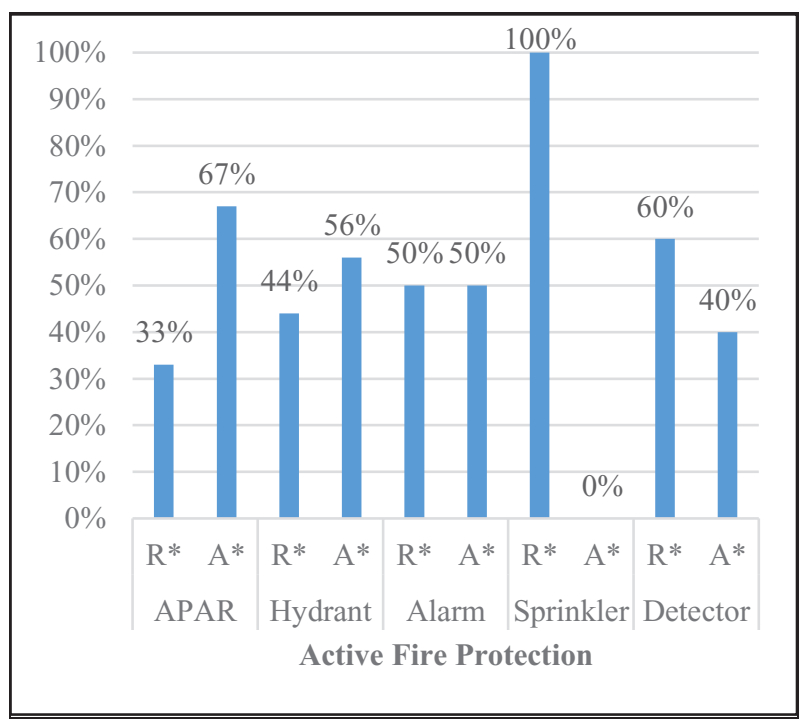

Fig 4. Comparison between $\mathrm{R}^{*}$ (Required) and $\mathrm{A}^{*}$ (Actual) Active Fire Protection

The passive fire protection consists of the emergency door, emergency stairs, exit direction, and assembly point. According to [16], there are seven requirements for the emergency door, but only five is fulfilled (71\%). Emergency doors can utilize side hinges that are designed to swing from any position and completed by exit sign marked out in the corridor [12]. Emergency stairs should meet six specifications, but only three fulfilled (50\%). It means not suitable with [12] due to no special identification, no floor level hints, and the use of space under the stairs to store goods, even not to store goods. The exit direction does not get any point $(0 \%)$ due to no installed exit directions yet. This also happens to the fourth passive fire protection $(0 \%)$ in which nothing assembly point installed. Whereas, according to [15], there should be three requirements that are met following [18] and [19]. Assembly point is critical so that people who save themselves know where the safe gathering place is. Only 8 out of 35 total requirements of passive fire protection fulfilled. The low percentage because many infrastructures do not meet the terms and conditions applied. It can be seen from each of the passive fire protection which less than $80 \%$ (Fig 5).

\subsection{Evacuation Map}

The evacuation route map is made based on the analysis of checklist result and derived from the old map in accordance with the fire regulation standards infrastructure. The map can be seen on the attachment (Fig. 6). For active protection devices such as fire extinguisher is placed every 15 meters [11], hydrant is available on each floor with the place close to the toilet, fire alarms are set near the stairs, and heat detectors are attached to the ceiling of each room [20]. While passive protection facilities such as emergency exits are located to the west, east, and hall where each is connected to the assembly point to facilitate the evacuation process $[12$, 
18]. Emergency stairs are located on four sides, namely west, east, near mosque, and near chemical engineering department. Each emergency staircase is equipped with floor number marks, exit directions [12], fire-resistant exit (approximately 2 hours) and panic bar as the handle so it is easily opened from the outside of the stairs to prevent the smoke entry into the fire escape [21]. Assembly points are located in the west and east of car park, and in front of the building hall. By dividing the gathering point, it is hoped that people can be more easily and quickly in the evacuation process.

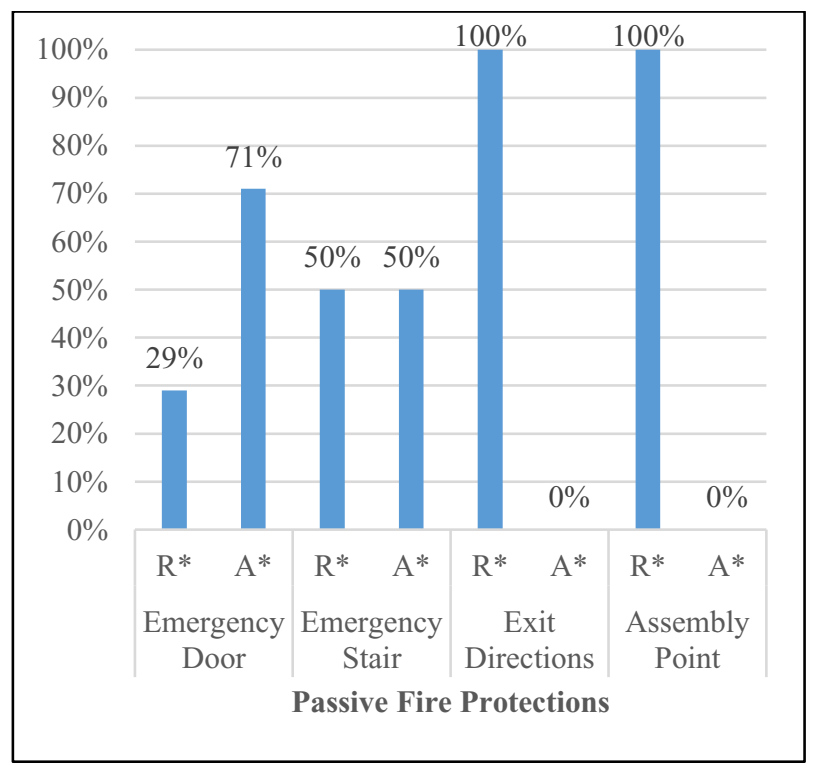

Fig 5. Comparison between $R^{*}$ (Required) and $A^{*}$ (Actual) passive fire protection

\section{Conclusions and Suggestions}

\subsection{Conclusions}

From the results of data processing and analysis that has been done, it can be concluded that:

a. According to the checklist results, most of the active and passive protection is still far from standard conformance rules. In total, only $38 \%$ of the protection met the standard in which $40 \%$ from active protection and $35 \%$ from passive protection. The active protection comprises of APAR 67\%; hydrant boxes $56 \%$; fire alarm $50 \%$; sprinkler $0 \%$; and fire detectors $40 \%$. Whereas the passive protection consists of door emergency $71 \%$; emergency staircase $50 \%$; assembly point $0 \%$; and directions $0 \%$.

b. Based on the observation and interviews in the building $\mathrm{KH}$. Mas Mansur, Islamic University of Indonesia, it needs an evacuation route map which is made based on the existing regulatory standards and consultation with experts.

\subsection{Suggestions}

Some suggestions for further actions are: a. Adjust both active and passive infrastructure by regulatory standards until reach enough category, so that awareness of prevention and fire countermeasure can be created.

b. Apply the proposed evacuation route map so that everyone inside the building could escape easily in case of a fire disaster.

\section{References}

1. S.K. Jia, X.-D. Liu, S.-J. Cai, J. Saf. Sci. Tech. 4 (2008)

2. D. Meng, H.-W. Yao, T.-Y. Cui, Y.-C. Sun, Procedia Eng. 135, 25-28 (2016)

3. I. Ismail, M. Taib, M.A.O. Mydin, Matec Web of Conf. 10, 06002, 1-7 (2014)

4. Y.N. Hu, Procedia Eng. 135, 524-530 (2016)

5. X. Liu, H. Zhang, Q. Zhu, Procedia Eng. 45, 643-648 (2012)

6. D. Ketabi, G.H. Halvani, Int. J. Occ. Hyg. 2(1), 6-9 (2010)

7. M.N. Ibrahim, K. Abdul-Hamida, M.S. Ibrahima, A. Mohd-Dina, R.M. Yunus, M.R. Yahya, Procedia Eng. 20, 317-324 (2011)

8. City News, Department of Fire and Rescue Management of Special Region Jakarta, Available at [http://www.jakartafire.net/news/detail/308/kampusstie-perbanas-terbakar] (2006)

9. A. Sudarno, Liputan 6, Available at [http://news.liputan6.com/read/2903007/kebakaranhanguskan-laboratorium-fateta-ipb-bogor] (2017)

10. Metro, Tribun Lampung, Available at [http://lampung.tribunnews.com/2017/11/05/kampus -stkip-kumala-kota-metro-ludes-terbakar-api] (2017)

11. Rule of the Ministry of Manpower and Transmigration, SNI No. Per.04/Men/1980 about the Terms and Maintenance of Fire Extinguisher, Article 2 (1980)

12. Rule of the Ministry of Public Works, No.26/PRT/M/2008 about the Technical Requirements of Fire Protection System on Building and Environment (2008)

13. Rule of the Ministry of Public Works, SNI No.20/PRT/M/2008 about the Technical Guidelines of Fire Protection Management in Urban Areas (2008)

14. Ministry of Public Works, Technical Guidance of Fire Building Fire Inspection (2005)

15. National Fire Protection Association, NFPA 101, Life Safety Codes (1995)

16. National Standardization Agency, SNI 03-3985-2000 about Procedure of Planning, Installation, and Testing of Fire Detection and Alarm System for Fire Hazards Prevention in Building (2000)

17. National Standardization Agency, SNI 03-3989-2000 about Planning Procedures, Installation of 
Automotive Sprinkler System for Fire Prevention in Building (2000)

18. National Standardization Agency, SNI 03-1746-2000 about the Procedures for Planning and Installation of Out-of-Road Facilities for Rescue of Fire Hazards in Building (2000)

19. National Standardization Agency, SNI 03-6571-2001 about Fire Smoke Control System in Building (2001)
20. National Standardization Agency, SNI 03-6574-2000 about Emergency Detection and Alarm System (2000)

21. National Standardization Agency, SNI 03-1735-2000 about Planning Procedures for Building and Environmental Access (2000) 


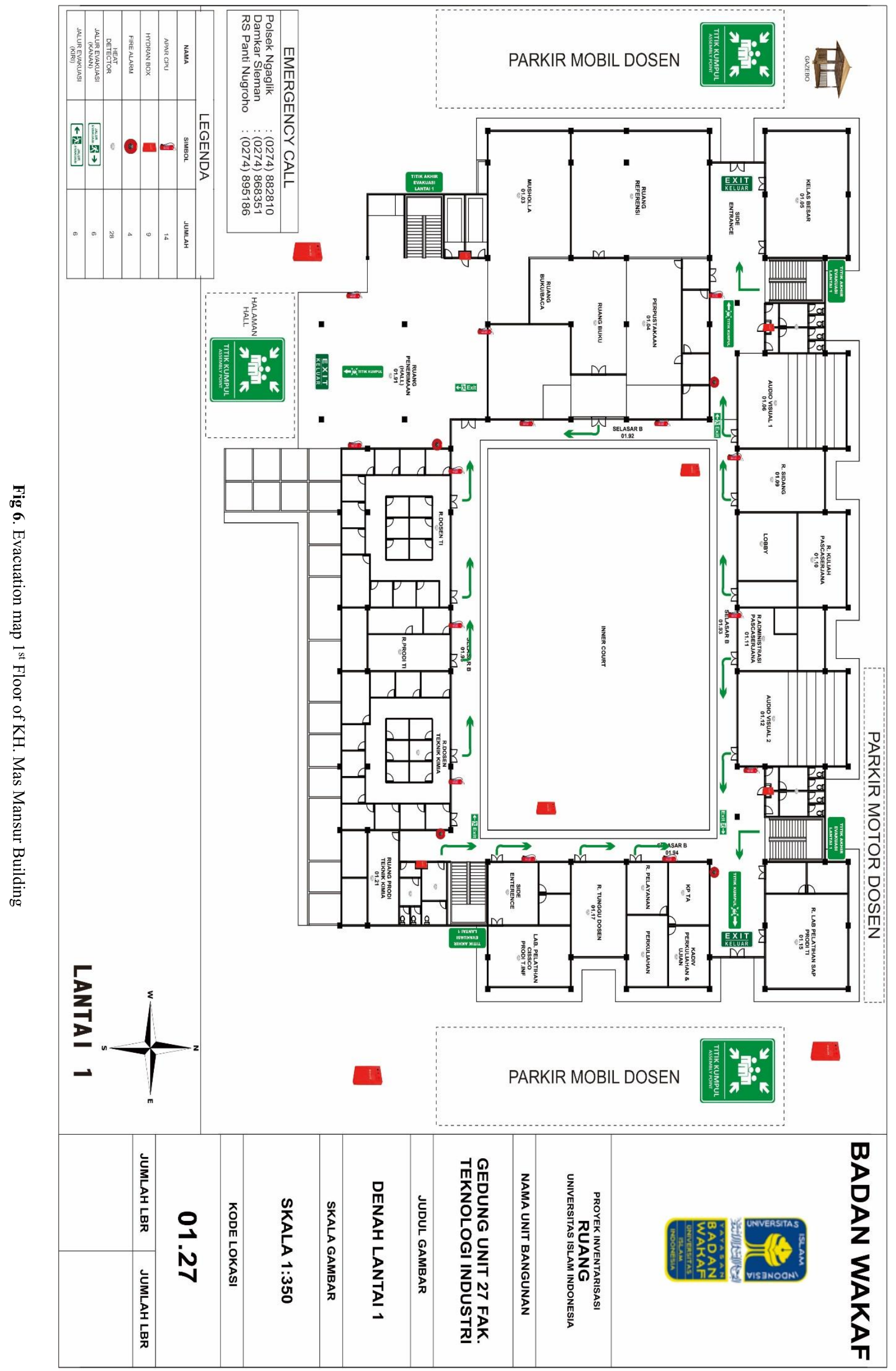

